\begin{tabular}{lllll}
$\mathbf{P}$ & $\mathbf{R}$ & $\mathbf{A}$ & $\mathbf{W}$ & $\mathbf{O}$ \\
\hline
\end{tabular}

ROCZNIKI NAUK PRAWNYCH

Tom XXIX, numer $2-2019$

DOI: http://dx.doi.org/10.18290/rnp.2019.29.2-1

AGNIESZKA KANIA

\title{
PRZESŁANKI I KONSEKWENCJE \\ ODPOWIEDZIALNOŚCI ZAWODOWEJ LEKARZY \\ - WYBRANE PROBLEMY \\ W ŚWIETLE PRZEPISÓW USTAWY O IZBACH LEKARSKICH
}

\section{WPROWADZENIE}

Niniejsze opracowanie będzie poświęcone wybranym zagadnieniom, związanym z reżimem odpowiedzialności zawodowej lekarzy. Mając na uwadze specyfikę zawodu lekarza oraz kierowane nierzadko pod jego adresem wyobrażenia społeczne (co de facto nie pozostaje obojętne z perspektywy samej istoty omawianego reżimu odpowiedzialności), podjęte rozważania rozpoczęte zostaną od analizy empirycznej, prezentującej poglądy opinii publicznej wobec osób wykonujących wspomniany zawód zaufania publicznego. W dalszej kolejności zostanie zwrócona uwaga na pewne kontrowersje interpretacyjne, które dotyczą nie tylko prawidłowego rozumienia samych podstaw odpowiedzialności zawodowej członków izb lekarskich, ale również normatywnego wymogu w postaci „odpowiedniego” stosowania na gruncie ustawy o izbach lekarskich przepisów Kodeksu karnego ${ }^{1}$, formułujących wskazania, jakimi powinien kierować się sąd przy orzekaniu kary.

\section{ZAWÓD LEKARZA W ŚWIETLE POGLĄDÓW OPINII PUBLICZNEJ}

W ramach stricte konwencjonalnej charakterystyki zawodu lekarza pojawia się nierzadko stwierdzenie, że wykonywanie tego zawodu, będącego egzemplifikacją

Dr AgniesZKa Kania - adiunkt w Katedrze Prawa Karnego i Postępowania Karnego, Wydział Prawa i Administracji Uniwersytetu Zielonogórskiego, Plac Słowiański 9, 65-068 Zielona Góra; e-mail: a.kania@wpa.uz.zgora.pl; https://orcid.org/0000-0001-6246-3172

${ }^{1}$ Ustawa z dnia 6 czerwca 1997 r. Kodeks karny, Dz. U. z 2018 r., poz. 1600 z późn. zm. [dalej cyt.: k.k.]. 
zawodu zaufania publicznego, powinno się kojarzyć zwłaszcza z obowiązkiem świadczenia usług o najwyższej jakości, przy jednoczesnym zachowaniu wysokich standardów etycznych oraz moralnych ${ }^{2}$. Podkreśla się bowiem, że każdy zawód zaufania publicznego to przecież $\dot{z}^{3}$,,[...] zawód polegający na obsłudze osobistych potrzeb ludzkich [...]"4. Dookreślając zatem istotę wspomnianej grupy zawodów nie bez racji do jego specyficznych właściwości zaliczono: ,a) [...] szczególną doniosłość prawidłowego i zgodnego z interesem publicznym wykonywania - istotnego $\mathrm{z}$ racji znaczenia, jaką dana dziedzina społecznej aktywności zawodowej odgrywa w społeczeństwie, oraz z racji konieczności zapewnienia ochrony gwarantowanych Konstytucją praw podmiotowych jednostki; b) powierzanie w warunkach wysokiego zaufania uprawiającym taki zawód informacji osobistych i dotyczących życia pry-

${ }^{2}$ Zob. Komunikat z badań. CBOS. Opinia spoleczna na temat zawodów zaufania publicznego. BS 73/2004, Warszawa: CBOS 2004, s. 2.

${ }^{3}$ Pojęcie zawodu zaufania publicznego zostało wprowadzone przepisami Konstytucji Rzeczypospolitej Polski (Konstytucja Rzeczypospolitej Polski z dnia 2 kwietnia 1997 r., Dz. U. Nr 78, poz. 483 z późn. zm. [dalej cyt. Konstytucja RP], która odwołując się do tego wyrażenia (art. 17 Konstytucji $\mathrm{RP}$ ), pominęła jego bliższą charakterystykę. Na temat definicji zawodu zaufania publicznego zob. m.in. L. Grzonka, J. Kosturbiec, Zawód zaufania publicznego. Przyczynek do dyskusji, „Studia Iuridica Lublinensia” t. IX (2007), s. 25; M. Tabernacka, Pojęcie zawodu zaufania publicznego, „Przegląd Prawa i Administracji” t. LXII (2004), s. 287; C. BANASIŃski, Samorząd gospodarczy i samorząd zawodowy, [w:] Prawo gospodarcze. Zagadnienia administracyjnoprawne, red. H. Gronkiewicz-Waltz, M. Wierzbowski, Warszawa: Wolters Kluwer 2011, s. 180 n.; W. ODRowąż-SYPNIEWsKi, W sprawie wykładni art. 17 Konstytucji Rzeczypospolitej Polskiej, „Przegląd Sejmowy” 2 (2001), s. 71; J. PITERA, Charakterystyka instytucji zaufania publicznego w orzecznictwie Trybunatu Konstytucyjnego, Sądu Najwyższego oraz sądów powszechnych, „Kwartalnik Prawa Publicznego” 4 (2007), s. 146; P. SARnecki, Pojęcie zawodu zaufania publicznego (art. 17 ust. 1 Konstytucji) na przyktadzie adwokatury, [w:] Konstytucja - Wybory - Parlament. Studia ofiarowane Zdzistawowi Jaroszowi, red. L. Garlicki, Warszawa: Liber 2000, s. 155; Tenże, Glosa do wyroku Sądu Najwyższego z dnia 29 maja 2001 r., sygn. I CKN 1217/98, „Palestra” 5-6 (2002), s. 187-188; K. WoJTCZAK, Reglamentacja form wykonywania zawodów zaufania publicznego w rozwiazaniach prawa polskiego i państw Unii Europejskiej, [w:] Zawody zaufania publicznego a interes publiczny - korporacyjna reglamentacja versus wolność wykonywania zawodu. Materiaty z konferencji zorganizowanej przez Komisję Polityki Społecznej i Zdrowia Senatu RP przy współudziale Ministerstwa Pracy i Polityki Spolecznej pod patronatem Marszałka Senatu RP Longina Pastusiaka, 8 kwietnia 2002 r., Warszawa: Dział Wydawniczy Kancelarii Senatu 2002, s. 40-41; M. KuleszA, Zawód zaufania publicznego, [w:] Zawody zaufania publicznego, s. 149 n.; W. WoŁPIUK, Zawód zaufania publicznego z perspektywy prawa konstytucyjnego, [w:] Zawody zaufania publicznego, s. 21; J. TACZKowsKA, Zawód dziennikarza w Polsce. Między misja a postannictwem, Bydgoszcz: Wydawnictwo UKW 2012, s. 169 n.; A. TRubalski, Samorzady zawodów zaufania publicznego na przykładzie samorządu radców prawnych. Analiza konstytucyjnoprawna, „Studia Iuridica Lublinensia” t. XXI (2014), s. 223 n.; P. Kuczma, Adwokat jako zawód zaufania publicznego w orzecznictwie Trybunału Konstytucyjnego, „Palestra” 3-4 (2012), s. 147 n.

${ }^{4}$ Wyrok Trybunału Konstytucyjnego z dnia 7 maja 2002 r., sygn. akt SK 20/00, OTK-A 2002, nr 3, poz. 29. 
watnego osób korzystających z ich usług; c) uznawanie tych informacji za tajemnicę zawodową, która nie może być ujawniona; d) objęcie osób dysponujących taką tajemnicą - w wypadku możliwości naruszenia istotnych dóbr jednostki w razie jej ujawnienia - immunitetem zwalniającym je od odpowiedzialności karnej za nieujawnienie informacji; e) korzystanie ze świadczeń tych zawodów często w razie nastąpienia realnego albo choćby potencjalnego niebezpieczeństwa dla dóbr jednostki o szczególnym charakterze (np. życie, zdrowie, wolność, godność, dobre imię); f) niepodleganie regułom hierarchii urzędniczej; g) występowanie sformalizowanej deontologii zawodowej oraz rękojmi należytego i zgodnego z interesem publicznym wykonywania zawodu, gwarantowana z jednej strony przez wysokie bariery dostępu do wykonywania każdego z zawodów zaufania publicznego, obejmujące nie tylko wymóg ukończenia odpowiedniego szkolenia, lecz również reprezentowanie odpowiedniego poziomu etycznego, z drugiej - sprawowaną $\mathrm{w}$ interesie publicznym pieczą organów samorządu zawodowego [... $]^{, 5}$.

Ze wskazanymi powyżej standardami, odnoszącymi się do wykonywania zawodów zaufania publicznego, łączy się integralnie konieczność skonfrontowania tych założeń zarówno z poglądami, dotyczącymi społecznej oceny prestiżu poszczególnych zawodów, ale również z oczekiwaniami opinii publicznej co do pożądanych kompetencji i zaangażowania ze strony osób je świadczących ${ }^{6}$. Prezentując to zagadnienie (zgodnie ze wskazaną w tytule problematyką) na przykładzie społecznych wyobrażeń kierowanych pod adresem zawodu lekarza, należałoby stwierdzić, iż wspomniany (verba legis niezdefiniowany) zawód ${ }^{7}$ cieszy się ogólnie wyso-

${ }^{5}$ Wyrok Trybunału Konstytucyjnego z dnia 2 lipca 2007 r., sygn. akt K 41/05, OTK-A 2007, nr 7, poz. 72. W innym zaś orzeczeniu podkreślono, iż: „«Zawody zaufania publicznego» wykonywane są - zgodnie z ich konstytucyjnym określeniem - w sposób założony i społecznie aprobowany, o ile ich wykonywaniu towarzyszy realne «zaufanie publiczne». Na zaufanie to składa się szereg czynników, wśród których na pierwszy plan wysuwają się: przekonanie o zachowaniu przez wykonującego ten zawód dobrej woli, właściwych motywacji, należytej staranności zawodowej oraz wiara w przestrzeganie wartości istotnych dla profilu danego zawodu", zob. wyrok Trybunału Konstytucyjnego z dnia 18 lutego 2004 r., sygn. akt P 21/02, OTK-A 2004, nr 2, poz. 9.

${ }^{6}$ Odrębną kwestią pozostaje natomiast zależność, jaka zachodzi pomiędzy postrzeganiem zawodu lekarza a sytuacją ekonomiczną kraju oraz ogólną oceną funkcjonowania służby zdrowia. Zob. szeroko na ten temat w raporcie Ośrodka Studiów, Analiz i Informacji Naczelnej Izby Lekarskiej, pt. Lekarze w badaniach opinii społecznej 2017, [w:] https://www.nil.org.pl/_data/assets/pdf_file/0007/125566/ Raport-Lekarze-w-badaniach-opinii-spolecznej-w-2017-roku.pdf [dostęp: 2.12.2018].

${ }^{7}$ Należy zaznaczyć, że w polskim ustawodawstwie brak jest legalnej definicji zawodu lekarza (takiej definicji nie zawiera zwłaszcza ustawa z dnia 5 grudnia 1996 r. o zawodach lekarza i lekarza dentysty, Dz. U. z 2018 r., poz. 617 z późn. zm.). Rekonstrukcja tego pojęcia może zatem nastąpić poprzez wyliczenie, na podstawie szeregu aktów normatywnych, określających zwłaszcza wymogi kompetencyjne, zakres czynności, do których lekarz jest uprawniony bądź zobowiązany. Zob. R. Kubiak, Prawo medyczne, Warszawa: C.H. Beck 2010, s. 17, a także J. ŻeBrowski, Socjologiczne 
kim, choć jednak nie najwyższym uznaniem ze strony polskiego społeczeństwa ${ }^{8}$. $\mathrm{Z}$ ostatnich badań sondażowych wynika, że zawód ten zajmuje ósme miejsce w hierarchii społecznie cenionych profesji (71\% najwyższego poparcia) $)^{9}$, ustępując miejsca (de facto różnym) zawodom, tj.: strażaka (87\%), profesora uniwersytetu $(82 \%)$, robotnika wykwalifikowanego $(81 \%)$, górnika $(80 \%)$, inżyniera pracującego w fabryce (78\%), pielęgniarki $(78 \%)$ oraz nauczyciela $(74 \%)^{10}$. Ogólnie wysokiego, społecznego poparcia dla tej grupy zawodowej nie nadwerężyły zatem protesty oraz strajki, do których wszak nierzadko dochodziło i nadal dochodzi w służbie zdrowia $^{11}$. Dostrzeżona zaś w niniejszym badaniu niższa ocena prestiżu zawodu

aspekty zawodu i pozycji społecznej - droga do tożsamości wychowawców profesjonalnych, „Studia Gdańskie. Wizje i Rzeczywistość" t. V (2008), s. 24 n.

${ }^{8}$ E. Nojszewska, System ochrony zdrowia w Polsce, Warszawa: Wolters Kluwer 2011, s. 68.

${ }^{9} \mathrm{~W}$ porównaniu do badań przeprowadzonych w $2008 \mathrm{r}$. jest to spadek z piątego miejsca. We wspomnianym badaniu zawód lekarza, w hierarchii najbardziej prestiżowych profesji, wyprzedzał zawód: profesora uniwersytetu, strażaka, górnika oraz pielęgniarki. Komunikat z badań. CBOS. Prestiż zawodów. BS/8/2009, Warszawa: CBOS 2009, s. 2. W piśmiennictwie wskazuje się, że: „Wyznacznikami wysokiego poważania są [...] wysokie wykształcenie, kwalifikacje i wiedza. Są nimi również użyteczność, kojarzona z realizacją misji społecznej i zaspokajaniem newralgicznych potrzeb [...]”, zob. H. DomaŃski, Z. SAwiński, K.M. SŁomcZYŃski, Prestiż zawodów w obliczu zmian społecznych: 1958-2008, „Studia Socjologiczne” 4 (2010), s. 113.

${ }^{10} \mathrm{Na}$ kolejnych, dalszych miejscach znaleźli się z kolei przedstawiciele następujących zawodów: rolnik indywidualny na średnim gospodarstwie (69\%), oficer zawodowy w randze kapitana (63\%), księgowy (63\%), adwokat (63\%), przedsiębiorca, właściciel dużej firmy (61\%), informatyk, analityk komputerowy (61\%), sędzia (60\%), właściciel małego sklepu (58\%), dyrektor dużego przedsiębiorstwa (58\%), sprzątaczka (57\%), policjant (53\%), sprzedawca w sklepie (53\%), dziennikarz (50\%), robotnik budowlany, niewykwalifikowany (49\%), burmistrz (46\%), referent w biurze, urzędnik (44\%), ksiądz (41\%), minister (37\%), makler giełdowy (36\%), radny gminy $(33 \%)$, poseł na Sejm $(32 \%)$, działacz partii politycznej (20\%). W komentarzu do niniejszego badania stwierdzono przy tym, że: „O zmianach w prestiżu zawodów, jakie obserwujemy w ostatnich latach, wydaje się przesądzać kryzys gospodarczy, trudna sytuacja na rynku pracy i bezrobocie coraz częściej dotykające ludzi młodych i wykształconych, a także możliwości zarobkowe w poszczególnych profesjach. Ogólnie rzecz biorąc, można sądzić, że Polacy odwracają się od zawodów inteligenckich, niżej wartościują ścieżkę kariery pracownika najemnego, zatrudnianego na stanowisku wymagającym etatu. Na prestiżu zyskują natomiast poszukiwane na rynku lub umożliwiające samodzielność profesje oparte na pracy fizycznej. Zapewne głównie z powodu sytuacji na rynku pracy rośnie w ostatnich latach szacunek i uznanie dla zawodów wymagających konkretnych kwalifikacji, dających możliwość zatrudnienia lub samozatrudnienia, a także dla działalności gospodarczej oraz zawodów kojarzonych ze sferą produkcyjną". Komunikat z badań. CBOS. Prestiż zawodów. BS/164/2013, Warszawa: CBOS 2013, s. 3 i 9. Wydaje się, że badanie to dowodzi, że społeczna ocena wykonywanych zawodów pozostaje w istocie zróżnicowana. Poszczególne zawody z racji swej użyteczności, potrzeby zaangażowania, wysiłku, posiadania niezbędnych umiejętności, wiedzy czy wykazania się na co dzień dużą odpowiedzialnością są odpowiednio mniej lub bardziej poważane oraz uznawane za mniej lub bardziej istotne w poglądach opinii publicznej. Zob. także Komunikat z badań. CBOS. Prestiż zawodów. $B S / 8 / 2009$, s. 1 .

${ }^{11}$ Komunikat z badań. CBOS. Prestiż zawodów. BS/32/1999, Warszawa: CBOS 1999, s. 1. 
lekarza w porównaniu z zawodem pielęgniarki stanowi - co nie wydaje się całkiem bezpodstawnym uzasadnieniem - następstwo nagłaśnianych w mediach informacji m.in. o: popełnianych błędach lekarskich, naruszaniu zasad etyki zawodowej przez lekarzy czy też dopuszczaniu się czynów korupcyjnych ${ }^{12}$.

Odnosząc się z kolei do społecznej oceny profesjonalizmu lekarzy (świadczących usługi w ramach NFZ), należy zaś odnotować, że - zgodnie z dostępnymi w tej materii wynikami badań - zdecydowana większość ankietowanych (67\%) uznaje, iż lekarze są kompetentni w wykonywaniu swojej profesji. Warto także zaznaczyć, że w tym samym badaniu $60 \%$ respondentów oceniło, iż przedstawiciele wspomnianej grupy zawodowej angażują się w swoją pracę, gdyż zależy im „na okazaniu pomocy pacjentom"13.

\section{PRZESŁANKI ODPOWIEDZIALNOŚCI ZAWODOWEJ LEKARZY}

Potwierdzeniem szczególnej misji zawodowej ${ }^{14}$, jaką powierzono osobom wykonującym zawód lekarza, pozostaje niewątpliwie preambuła, zawarta w Kodeksie Etyki Lekarskiej ${ }^{15}$. Mając na uwadze płynące $z$ jej treści zobowiązania, a także

${ }^{12}$ Komunikat z badań. CBOS. Prestiż zawodów. BS/164/2013, s. 3.

${ }^{13}$ Komunikat z badań. CBOS. Opinie o funkcjonowaniu opieki zdrowotnej. BS/113/2016, Warszawa: CBOS 2016, s. 4.

${ }^{14}$ K. Pollak, Uczniowie Hipokratesa, thum. T. Dobrzański, Warszawa: Wiedza Powszechna 1970, s. 151 n.; K. Tadajczyk, Status społeczno-prawny i odpowiedzialność lekarza w prawie rzymskim, Łódź: Drukarnia Cyfrowa 2014, s. 45.

15 „Przyjmuję z szacunkiem i wdzięcznością dla moich Mistrzów nadany mi tytuł lekarza i w pełni świadomy związanych z nim obowiązków przyrzekam: obowiązki te sumiennie wypełniać; służyć życiu i zdrowiu ludzkiemu; według najlepszej mej wiedzy przeciwdziałać cierpieniu i zapobiegać chorobom, a chorym nieść pomoc bez żadnych różnic, takich jak: rasa, religia, narodowość, poglądy polityczne, stan majątkowy i inne, mając na celu wyłącznie ich dobro i okazując należny im szacunek; nie nadużywać ich zaufania i dochować tajemnicy lekarskiej nawet po śmierci chorego; strzec godności stanu lekarskiego i niczym jej nie splamić, a do kolegów lekarzy odnosić się z należną im życzliwością, nie podważając zaufania do nich, jednak postępując bezstronnie i mając na względzie dobro chorych; stale poszerzać swą wiedzę lekarską i podawać do wiadomości świata lekarskiego wszystko to, co uda mi się wynaleźć i udoskonalić. Przyrzekam to uroczyście!”, zob. w tym zakresie Obwieszczenie nr 1/04/IV Prezesa Naczelnej Rady Lekarskiej z dnia 2 stycznia 2004 r. w sprawie ogłoszenia jednolitego tekstu uchwały w sprawie Kodeksu Etyki Lekarskiej, w którym stwierdzono, że: „Na podstawie $\S 2$ uchwały Nr 5 Nadzwyczajnego VII Krajowego Zjazdu Lekarzy z dnia 20 września 2003 r. zmieniającej uchwałę w sprawie Kodeksu Etyki Lekarskiej (Biuletyn NRL z 2003 r. Nr 6/80/) ogłasza się w załączniku do niniejszego obwieszczenia jednolity tekst uchwały Nadzwyczajnego II Krajowego Zjazdu Lekarzy z dnia 14 grudnia 1991 r. w sprawie Kodeksu Etyki Lekarskiej (Biuletyn NRL z 1994 r. Nr 1/24/), z uwzględnieniem zmian wprowadzonych uchwałą Nr 5 Nadzwyczajnego VII Krajowego Zjazdu Lekarzy z dnia 20 września 2003 r. zmieniającej uchwałę w sprawie Kodeksu Etyki Lekarskiej (Biuletyn NRL z 2003 r. Nr 6/80/)", zob. także 
znaną łacińską maksymę, w myśl której honor przynosi ciężar (honos habet onus), wypadałoby stwierdzić, że wszelkie uchybienia wykonywanemu zawodowi lekarza w sposób nieunikniony muszą podlegać zaostrzonym rygorom. W sytuacji, gdy dostrzeżone nieprawidłowości okażą się niezgodne z przepisami prawa bądź zasadami deontologii zawodowej wówczas staną się $-\mathrm{z}$ oczywistych względów - przedmiotem odpowiedzialności prawnej. Jedną z postaci wspomnianej odpowiedzialności, interesującej z perspektywy niniejszego opracowania, pozostaje odpowiedzialność zawodowa, której przesłanki sformułowano w art. 53 ustawy o izbach lekarskich ${ }^{16}$. W przepisie tym expressis verbis przewidziano, że członkowie izb lekarskich podlegają odpowiedzialności zawodowej za naruszenie zasad etyki lekarskiej oraz przepisów związanych z wykonywaniem zawodu lekarza ${ }^{17}$. $Z$ jego treści wynika zatem, że przewinienie zawodowe może $\mathrm{w}$ istocie polegać na uchybieniu zasadom etyki lekarskiej albo przepisom związanym z wykonywaniem zawodu lekarza, ale również i na łącznym naruszeniu tych zasad oraz przepisów ${ }^{18}$. W ocenie Sądu Najwyższego: „[...] takie dwupostaciowe określenie deliktu dyscyplinarnego wymaga przeprowadzenia przez sąd dyscyplinarny w procesie orzekania dwóch sformalizowanych czynności procesowych. Pierwsza dotyczy określenia rodzaju deliktu dyscyplinarnego, zaś druga polega na skonkretyzowaniu znamion przewinienia dyscyplinarnego poprzez poczynienie ustaleń faktycznych wskazu-

Kodeks Etyki Lekarskiej, [w:] http://www.nil.org.pl/_data/assets/pdf_file/0003/4764/Kodeks-Etyki-Lekarskiej.pdf [dostęp: 4.12.2018].

${ }^{16}$ Ustawa o izbach lekarskich z dnia 2 grudnia 2009 r., Dz. U. z 2018 r., poz. 168 z późn. zm. W odniesieniu zaś do kręgu podmiotów deliktu określonego w art. 53 cytowanej ustawy w orzecznictwie zwrócono uwagę, że: „Wprawdzie, zgodnie z art. 53 ustawy z 2009 r. o izbach lekarskich, odpowiedzialności w trybie tej ustawy podlegają członkowie izb lekarskich, którymi są również emerytowani lekarze i lekarze dentyści, jednak jest to odpowiedzialność zawodowa, na co wskazuje tytuł rozdziału 5 ustawy o izbach lekarskich, co może zawężać krąg podmiotów deliktu określonego w art. 53 ustawy do osób wykonujących zawód lekarza lub lekarza dentysty".

${ }^{17}$ D. KarkowsKa, Zawody medyczne, Warszawa: Wolters Kluwer 2012, s. 289; A. KorYTKowSKA, Problem zgodności Kodeksu etyki lekarskiej z Konstytucja RP, „Ruch Prawniczy, Ekonomiczny i Socjologiczny" 1 (2009), s. 53 n.; R. PATRYN, Lekarski egzamin państwowy. Prawo medycznie orzecznictwo lekarskie. Kompendium wiedzy dla absolwentów wydziatów lekarskich i lekarsko-dentystycznych, Warszawa: Medyk 2014, s. 105.

${ }^{18}$ Należy jednak zastrzec, że: ,[...] racjonalny ustawodawca nie może obejmować sankcjami prawnymi zachowań, które są zgodne z nakazem, zakazem lub dozwoleniem wynikającym z obowiązujących norm prawnych. Wprowadzając do ustawy o izbach lekarskich sankcje prawne określone $\mathrm{w}$ art. 42 związane $\mathrm{z}$ postępowaniem sprzecznym z zasadami etyki i deontologii zawodowej nie mógł więc ich ustawodawca łączyć z takimi zachowaniami, które były wykonaniem występującego w ustawie obowiązku lub mieściły się w ramach zakreślonego ustawą dozwolenia”, zob. uchwałę Trybunału Konstytucyjnego z dnia 17 marca 1993 r., sygn. akt W 16/92, OTK 1993, poz. 16. 
jących na ich realizację"19. Na marginesie należy odnotować, że w przytoczonym fragmencie orzeczenia (sformułowanym na gruncie ustawy o izbach lekarskich) uwagę niewątpliwie zwraca użyta w nim terminologia. Wynikająca z cytowanej wypowiedzi próba usynonimicznienia wyrażeń „odpowiedzialność zawodowa” i „odpowiedzialność dyscyplinarna” nie znajduje, co wymaga zaakcentowania, normatywnego wsparcia w przepisach ustawy o izbach lekarskich. W omawianej regulacji odwołano się expressis verbis do pojęcia „odpowiedzialności zawodowej”"20, jako sformułowania bardziej przystającego do tego rodzaju odpowiedzialności, ponoszonej przez członków izb lekarskich ${ }^{21}$. Jednocześnie trzeba w tym miejscu podkreślić, że ponoszenie odpowiedzialności zawodowej przez lekarza nie wyłącza możliwości poniesienia przez niego odpowiedzialność dyscyplinarnej, opartej na stosunku pracy lub na stosunku służbowym (np. w przypadku zatrudnienia lekarza w wojsku czy w policji ${ }^{22}$.

${ }^{19}$ Postanowienie Sądu Najwyższego z dnia 11 lutego 2016 r., sygn. akt SDI 71/15, OSNKW 2016, nr 5, poz. 34.

${ }^{20}$ Do takiej terminologii odwołuje się także m.in. ustawa z dnia 1 lipca 2011 r. o samorządzie pielęgniarek i położnych, Dz. U. z 2018 r., poz. 916 z późn. zm.; ustawa z dnia 19 kwietnia 1991 r. o izbach aptekarskich, Dz. U. z 2016 r., poz. 1496 z późn. zm.; ustawa z dnia 18 lipca 1950 r. o odpowiedzialności zawodowej fachowych pracowników służby zdrowia, Dz. U. Nr 36, poz. 332 z późn. zm.

${ }^{21}$ M. KozIK, Odpowiedzialność zawodowa lekarzy, [w:] A. FiutaK [I IN.], Odpowiedzialność prawna pracowników medycznych. Przepisy - przykłady - orzecznictwo, Warszawa: C.H. Beck 2013, s. 8. Zdaniem tego Autora: „Pojęcie «odpowiedzialność dyscyplinarna» sugeruje, że chodzi o ukaranie za naruszenie dyscypliny, tymczasem nie o dyscyplinę pracy tu chodzi, lecz o ukaranie za nienależyte wykonywanie zawodu lub naruszenie etyki zawodowej, dlatego określenie «odpowiedzialność zawodowa» bardziej przystaje do tego typu odpowiedzialności”. Zob. także wyrok Trybunału Konstytucyjnego z dnia 29 czerwca 2010 r., sygn. akt P 28/09, LEX nr 602879, w którym podniesiono: „[...] postępowanie dyscyplinarne musi być dostosowane do specyfiki danej grupy zawodowej. $\mathrm{Z}$ tego też względu ustawowe uregulowania tej problematyki niejednokrotnie znacznie różnią się od siebie. Odmienności dotyczą zarówno katalogu przewinień dyscyplinarnych i kar grożących za ich popełnienie, jak i organów egzekwujących odpowiedzialność dyscyplinarną oraz samej procedury. Okolicznością mającą istotne znaczenie z punktu widzenia przyjętego modelu odpowiedzialności dyscyplinarnej jest charakter wykonywanego zawodu. W wypadku osób wykonujących tzw. zawód zaufania publicznego postępowanie dyscyplinarne prowadzone jest przez organy samorządu zawodowego, do którego osoby te należą z mocy prawa. W wypadku osób wykonujących inny zawód postępowanie dyscyplinarne prowadzone jest przez podmioty, którym osoby te podlegaja (np. pracodawców, przełożonych służbowych) lub organy powołane przez te podmioty na mocy przepisów ustawowych (np. komisje dyscyplinarne)". Zob. również W. WANATOWSKA, W. KulesZA, Odpowiedzialność prawna lekarza, Warszawa: Wydawnictwo Prawnicze 1988, s. 7; E. ZielińskA, Odpowiedzialność zawodowa i karna lekarza w Polsce (Perspektywa prawnoporównawcza), „Państwo i Prawo" 3 (1991), s. 26-28; A. FiutaK, Prawo w medycynie, Warszawa: C.H. Beck 2011, s. 101

${ }^{22}$ R. GiętKowski, Odpowiedzialność dyscyplinarna w prawie polskim, Gdańsk: Wydawnictwo Uniwersytetu Gdańskiego 2013, s. 50. Zob. także art. 54 ustawy o izbach lekarskich, w którym przewidziano, że: „1. Postępowanie w przedmiocie odpowiedzialności zawodowej lekarzy toczy się niezależnie od postępowania karnego lub postępowania dyscyplinarnego dotyczącego tego samego 
Koncentrując się w niniejszym opracowaniu na wybranych zagadnieniach z zakresu odpowiedzialności zawodowej lekarzy i tym samym przechodząc do wspomnianych powyżej podstaw tego reżimu odpowiedzialności, warto w ramach ogólniejszej refleksji zaznaczyć, że ustawa o izbach lekarskich nie określa zamkniętego katalogu czynów uznawanych verba legis za przewinienie zawodowe, a ponadto nie wskazuje również rodzaju kary, jaka mogłaby grozić za jego popełnienie. $\mathrm{Z}$ brzmienia cytowanego powyżej art. 53 ustawy o izbach lekarskich wynika, że podstawową materię, pozwalającą na zakwalifikowanie określonego zachowania jako przykładu przewinienia zawodowego stanowi - po pierwsze Kodeks Etyki Lekarskiej (art. 38 pkt 1 ustawy o izbach lekarskich ${ }^{23}$ ), a po drugie szereg aktów normatywnych, które normują zasady udzielania przez lekarzy świadczeń zdrowotnych ${ }^{24}$.

W odniesieniu do pierwszej z wymienionych regulacji, czyli Kodeksu Etyki Lekarskiej (stanowiącego załącznik do obwieszczenia nr 1/04/IV Prezesa Naczelnej Rady Lekarskiej z dnia 2 stycznia 2004 r.) warto w pierwszej kolejności nadmienić, że już na gruncie ustawy o izbach lekarskich (art. 8) przesądzono, że członkowie samorządu lekarskiego zostali zobowiązani do przestrzegania zasad etyki lekarskiej, przepisów związanych z wykonywaniem zawodu lekarza, jak również do stosowania się do uchwał organów izb lekarskich. Zawarte zaś we wspomnianym powyżej art. 38 pkt 1 ustawy o izbach lekarskich upoważnienie do uchwalenia zasad etyki lekarskiej stanowi $\mathrm{w}$ istocie ustawowe potwierdzenie: ,[...] powszechnie uznawanego prawa korporacji lekarskiej (także i innych korporacji zawodowych) do określania zasad deontologicznych $\mathrm{w}$ zgodzie $\mathrm{z}$ uznawanym przez te korporacje systemem wartości" ${ }^{25}$. Choć uchwalony przez Nadzwyczajny Krajowy Zjazd Lekarzy Kodeks Etyki Lekarskiej nie jest wprawdzie źródłem prawa w rozumieniu

czynu. 2. Postępowanie w przedmiocie odpowiedzialności zawodowej lekarzy może być zawieszone do czasu ukończenia postępowania karnego lub dyscyplinarnego, o ile ich wynik może mieć wpływ na rozstrzygnięcie w postępowaniu w przedmiocie odpowiedzialności zawodowej lekarzy".

${ }^{23}$ Zob. przypis nr 15.

${ }^{24} \mathrm{~W}$ tym zakresie można wymienić nie tylko cytowaną ustawę o izbach lekarskich, lecz także ustawę z dnia 5 grudnia 1996 r. o zawodach lekarza i dentysty; ustawę z dnia 6 listopada 2008 r. o prawach pacjenta i Rzeczniku Praw Pacjenta, Dz. U. z 2017 r., poz. 1318 z późn. zm.; ustawę z dnia 15 kwietnia 2011 r. o działalności leczniczej, Dz. U. z 2018 r., poz. 2190 z późn. zm.; ustawę z dnia 19 sierpnia 1994 r. o ochronie zdrowia psychicznego, Dz. U. z 2018 r., poz. 1878 z późn. zm. Zob. także KozIK, Odpowiedzialność zawodowa lekarzy, s. 26 n.; M. BrzozowsKa-KruczeK, Zawody medyczne, Warszawa: Wolters Kluwer 2013, s. 40-41; D. KARKowsKa, Prawo medyczne dla pielęgniarek, Warszawa: Wolters Kluwer 2013, s. 115-116.

${ }^{25}$ Zob. postanowienie Trybunału Konstytucyjnego z dnia 7 października 1992 r., sygn. akt U 1/92, OTK 1992, nr 2, poz. 38. 
przepisów Konstytucji $\mathrm{RP}^{26}$, to jednak trzeba w tym miejscu zaznaczyć, że jego normy dookreślają de facto treść norm prawnych, wynikających z ustawy o izbach lekarskich. Stąd też można by wręcz zaryzykować stwierdzeniem, iż właśnie w ten sposób analizowane normy etyczne zostały niejako „inkorporowane” do systemu obowiązującego prawa ${ }^{27}$.

Przyjmując zatem, że naruszenie norm zawartych w Kodeksie Etyki Lekarskiej skutkuje pociągnięciem do odpowiedzialności zawodowej, trudno byłoby jednak pominąć, że we wspominanej regulacji nie zdefiniowano zarówno samych zasad etyki lekarskiej, jak również nie podano nawet przykładowego katalogu zachowań, które należałoby uznać za niezgodne z nimi. Ogólne stwierdzenie, iż zasady etyki lekarskiej wynikają z ogólnych norm etycznych (art. 1 ust. 1 Kodeksu Etyki Lekarskiej), a naruszeniem godności zawodu jest zaś każde postępowanie lekarza, które podważa zaufanie do wykonywanego zawodu (art. 1 ust. 3 Kodeksu Etyki Lekarskiej) skłania do konkluzji, że powołana regulacja wskazuje na niezwykle szerokie, bliżej nieskonkretyzowane spectrum zachowań, które można by w praktyce ocenić jako uchybiające etyce lekarskiej. Kodeksowe normy kreują de facto bardzo pojemną interpretacyjnie, a wręcz nieco idealistyczną wizję prawidłowego wypełniania obowiązków przez lekarzy. W konsekwencji nasuwa się refleksja, że uznanie pewnych zachowań, jako czynów stanowiących przejaw nieprzestrzegania zasad etyki lekarskiej, musi wzbudzać w nieunikniony sposób pewne wątpliwości

${ }^{26}$ Zob. J. WyrembaK, Naruszenie zasad etyki lub deontologii jako podstawa odpowiedzialności zawodowej lekarza, „Studia Iuridica” t. XLIII (2004), s. 245 n.; TenżE, Kodeks etyki lekarskiej a system prawa, „Państwo i Prawo” 10 (2003), s. 30 n. Na temat aktualnego ujęcia katalogu źródeł prawa zob. m.in. wyrok Trybunału Konstytucyjnego z dnia 28 czerwca 2000 r., sygn. akt K 25/99, OTK 2000, nr 5, poz. 141, a także wyrok Trybunału Konstytucyjnego z dnia 1 grudnia 1998 r., sygn. akt K 21/98, OTK 1998, nr 7, poz. 116; wyrok Trybunału Konstytucyjnego z dnia 12 lipca 2001 r., sygn. akt SK 1/01, OTK 2001, nr 5, poz. 127.

${ }^{27}$ Postanowienie Sądu Najwyższego z dnia 11 lutego 2016 r., sygn. akt SDI 71/15, OSNKW 2016, $\mathrm{nr} 5$, poz. 34. Warto również przypomnieć stanowisko Trybunału Konstytucyjnego (zaprezentowane wprawdzie na gruncie przepisów poprzednio obowiązującej ustawy z dnia 17 maja 1989 r. o izbach lekarskich, ale zachowujące nadal aktualność), w którym stwierdzono: „,[...] normy etyczne są autonomiczne w stosunku do norm prawnych. To normy prawne powinny posiadać legitymację aksjologiczną, normy etyczne nie potrzebują legitymacji jurydycznej. Pozytywne prawo, szczególnie w systemie pluralistycznym, jest zawsze wynikiem kompromisu różnych sił politycznych i społecznych odgrywających rolę w życiu publicznym. Prawo nie może być pełnym odbiciem moralności. Stąd pochodzą różnice zakresów pomiędzy obowiązującym systemem prawa a występującymi w społeczeństwie systemami norm etycznych”, zob. uchwała Trybunału Konstytucyjnego z dnia 17 marca 1993 r., sygn. akt W 16/92, OTK 1993, poz. 16; zob. także wyrok Trybunału Konstytucyjnego z dnia 23 kwietnia 2008 r., sygn. akt SK 16/07, OTK-A 2008, nr 3, poz. 45. Zob. również L. BoseK, Etyka lekarska, [w:] Prawo wobec medycyny i biotechnologii. Zbiór orzeczeń z komentarzami, red. M. Safjan, Warszawa: Wolters Kluwer 2011, s. 29-30. 
z punktu widzenia fundamentalnych zasad, które powinny być respektowane na płaszczyźnie odpowiedzialności typu represyjnego.

Od podniesionych tutaj wątpliwości nie jest wolna także druga z zasygnalizowanych podstaw odpowiedzialności za delikt zawodowy. Nieprzestrzeganie postanowień, wynikających z aktów normatywnych, które określają zasady udzielania przez lekarzy świadczeń zdrowotnych ${ }^{28}$ wydaje się również (a przynajmniej prima facie) określeniem bardzo pojemnym treściowo. Stąd też, tak szerokie ujęcie rozważanej podstawy odpowiedzialności zawodowej (nawet przy uwzględnieniu jej specyfiki ${ }^{29}$ ) może niekiedy implikować podobne do wskazanych powyżej kontrowersji natury gwarancyjnej.

\section{PRAWNE KONSEKWENCJE PRZEWINIENIA ZAWODOWEGO - ZNACZENIE PRZEPISÓW KARNOMATERIALNYCH PRZY WYBORZE KARY ORZEKANEJ WOBEC CZŁONKÓW IZB LEKARSKICH}

Jedną z niemal najbardziej oczywistych konsekwencji prawnych popełnienia przez członków izb lekarskich przewinienia zawodowego pozostaje zastosowanie kary ${ }^{30}$, których katalog został ujęty w art. 83 o izbach lekarskich ${ }^{31}$. Wśród wspomnianych kar ustawodawca przewidział: 1) upomnienie; 2) naganę; 3) karę pieniężną; 4) zakaz pełnienia funkcji kierowniczych $\mathrm{w}$ jednostkach organizacyjnych ochrony zdrowia na okres od roku do pięciu lat; 5) ograniczenie zakresu czynności w wykonywaniu zawodu lekarza na okres od sześciu miesięcy do dwóch lat; 6) zawieszenie prawa wykonywania zawodu na okres od roku do pięciu lat; 7) pozbawienie prawa wykonywania zawodu. We wspomnianym powyżej (ale również dalszych) przepisach

${ }^{28}$ Postanowienie Sądu Najwyższego z dnia 11 lutego 2016 r., sygn. akt SDI 70/15, Legalis nr 1430517. W orzeczeniu tym stwierdzono: „Osoba wykonująca zawód lekarza z natury rzeczy zobowiązana jest do zapoznawania się ze zmieniającymi się przepisami dotyczącymi tego zawodu [...]".

${ }^{29}$ Zob. w tym zakresie także wyrok Trybunału Konstytucyjnego z dnia 27 lutego 2001 r., sygn. akt K 22/00, OTK 2001, nr 3, poz. 48.

${ }^{30}$ Warto odnotować, że w art. 82 ust. 2 ustawy o izbach lekarskich przewidziano, iż w przypadku przewinienia mniejszej wagi albo jeżeli orzeczenie wobec obwinionego kary byłoby oczywiście niecelowe ze względu na rodzaj i wysokość kary prawomocnie orzeczonej za ten sam czyn w innym postępowaniu przewidzianym przez ustawy, a interes pokrzywdzonego temu się nie sprzeciwia, sąd lekarski może umorzyć postępowanie.

${ }^{31} \mathrm{~W}$ tym miejscu trzeba wspomnieć, że zgodnie z orzecznictwem: „Sąd lekarski orzekający w sprawie odpowiedzialności zawodowej lekarza - uznawszy oskarżonego za winnego popełnienia zarzuconego mu czynu - nie może odstąpić od wymierzenia kary”, zob. wyrok Sądu Najwyższego z dnia 18 lutego 1994 r., sygn. akt I PLN 1/94, Legalis nr 28453; zob. także A. STYCHLERZ, Lekarz przed sądem lekarskim, „Forum Medycyny Rodzinnej” 4 (2009), s. 341-342. 
pominięto jednocześnie określenie ustawowych wskazań, którymi powinien kierować się sąd lekarski, decydując o doborze właściwej sankcji. Stosowną jednak „podpowiedź” w tym zakresie zawiera art. 112 pkt 2 ustawy o izbach lekarskich, który wymaga „odpowiedniego” stosowania niektórych przepisów z Kodeksu karnego, poświęconych niniejszej materii (tj. art. 3 k.k. oraz art. 53 k.k.) ${ }^{32}$. Przyjęty tutaj sposób regulacji pozostaje przy tym w zgodzie z obowiązującymi zasadami techniki prawodawczej ${ }^{33}$, które dopuszczają możliwość posłużenia się odesłaniem $^{34}$, wskazującym, iż właściwa norma, mająca znaleźć zastosowanie w danym przypadku, znajduje się $\mathrm{w}$ tekście innego aktu normatywnego ${ }^{35}$. Konkretyzując zaś sam model „odpowiedniego” stosowania przepisów, należałoby przypomnieć, że zgodnie $\mathrm{z}$ utrwalonym poglądem doktryny oraz orzecznictwa może ono w istocie przybrać trojaką postać i w konsekwencji polegać na zastosowaniu danego przepisu wprost bądź z odpowiednimi modyfikacjami albo też na odmowie jego zastosowania $\mathrm{z}$ uwagi na specyfikę danej materii regulacyjnej ${ }^{36}$. $\mathrm{Z}$ powyższego wynika, że rozważane „odpowiednie” stosowanie przepisów nie posiada charakteru jednolitej czynności, co oznacza, iż tego rodzaju zabieg interpretacyjny może de facto prowadzić do zróżnicowanych rezultatów.

${ }^{32}$ Tego rodzaju odesłanie dostrzega się również w art. 88 pkt 2 ustawy z dnia 1 lipca 2011 r. o samorządzie pielęgniarek i położnych, który stanowi, że: „W sprawach nieuregulowanych w ustawie do postępowania $\mathrm{w}$ przedmiocie odpowiedzialności zawodowej stosuje się odpowiednio przepisy [... 2) rozdziałów I - III i art. 53 ustawy z dnia 6 czerwca1997 r. (Dz. U. Nr 88, poz. 553 ze zm.)".

${ }^{33}$ Zob. § 158 rozporządzenia Prezesa Rady Ministrów z dnia 20 czerwca 2002 r. w sprawie „Zasad techniki prawodawczej”, Dz. U. z 2016 r., poz. 283 z późn. zm.

${ }^{34} \mathrm{Na}$ temat dopuszczalności stosowania odesłań zob. wyrok Trybunału Konstytucyjnego z dnia 29 czerwca 2006 r., sygn. akt P 30/05, OTK-A 2006, nr 6, poz. 70; wyrok Trybunału Konstytucyjnego z dnia 27 listopada 2006 r., sygn. akt K 47/04, OTK-A 2006, nr 10, poz. 153; wyrok Trybunału Konstytucyjnego z dnia 11 stycznia 2000 r., sygn. akt K 7/99, OTK 2000, nr 1, poz. 2.

${ }^{35}$ Uchwała Sądu Najwyższego z dnia 30 stycznia 2001 r., sygn. akt I KZP 50/00, OSNKW 2001, nr 3-4, poz. 16.

${ }^{36}$ L. MorawsKi, Wyktadnia w orzecznictwie sądów. Komentarz, Toruń: TNOiK Dom Organizatora 2002, s. 299; K. OpAŁEK, J. WróBlewsKi, Zagadnienia teorii prawa, Warszawa: Wydawnictwo Naukowe 1969, s. 65; uchwała Sądu Najwyższego z dnia 6 grudnia 2000 r., sygn. akt III CZP 41/00, OSNC 2001, nr 4, poz. 57, w której stwierdzono: „Powszechnie przyjmuje się, że mówiąc najkrócej, stosowanie przepisu «odpowiednie» może polegać na jego zastosowaniu wprost albo z pewnymi modyfikacjami usprawiedliwionymi odmiennością stanu «podciąganego» pod dyspozycję stosowanego przepisu, bądź wreszcie na niedopuszczalności jego stosowania do rozpatrywanego stanu w ogóle. Ta niedopuszczalność może przy tym wynikać albo bezpośrednio z treści wchodzących $\mathrm{w}$ grę regulacji prawnych, albo z tego, że zastosowania danej normy nie dało się pogodzić ze specyfiką i odmiennością rozpoznawanego stanu". Zob. także wyrok Sądu Najwyższego z dnia 29 października 2009 r., sygn. akt SDI 22/09, Legalis nr 303967; G. WIERCZYŃSKI, Redagowanie i ogłaszanie aktów normatywnych. Komentarz, Warszawa: Wolters Kluwer 2016, s. 793; J. NowACKI, Studia z teorii prawa, Kraków: Kantor Wydawniczy Zakamycze 2003, s. 452; M. HAuSER, Odpowiednie stosowanie przepisów prawa - uwagi porzadkujace, „Acta Universitatis Wratislaviensis” t. LXV (2005), s. 159-162. 
Mając na względzie dotychczasowe ustalenia, warto jednak zaznaczyć, że na jeszcze inny, a przy tym wątpliwy kierunek wykładni zaakcentowanego tutaj „odpowiedniego" stosowania wspomnianej grupy przepisów prawnokarnych zwrócono uwagę w orzecznictwie Sądu Najwyższego. W jednym z orzeczeń podniesiono, że obecny na gruncie rozważanej regulacji wymóg „odpowiedniego" stosowania został wprowadzony: ,[...] przez ustawodawcę m.in. dlatego, że okręgowe sądy lekarskie i Naczelny Sąd Lekarski składają się z lekarzy, a nie sędziów zawodowych"37. Rozwijając ten punkt widzenia, w dalszej argumentacji starano się podkreślić - co pozostaje jednak trudne do zaakceptowania - że wspomniana klauzula „odpowiedniego" stosowania będzie pełniła niejako asekuracyjną rolę, kreującą sui generis usprawiedliwienie w przypadku ewentualnych uchybień określonym przepisom prawnokarnym, stosowanym przez nieprawnicze składy sędziowskie ${ }^{38}$.

\section{CZYNNIKI WPŁYWAJĄCE NA WYBÓR KARY ORZEKANEJ WOBEC LEKARZY ZA PRZEWINIENIE ZAWODOWE}

Zgodnie z wcześniejszymi ustaleniami, rozpoznanie ustawowych wskazań wpływających na decyzję o zastosowaniu kary wobec członków izb lekarskich za przewinienie zawodowe wymaga odwołania się do określonych przepisów karnomaterialnych oraz ich wykładni. Mając zatem na uwadze odsyłającą treść regulacji art. 112 pkt 2 ustawy o izbach lekarskich oraz ogólnie niekwestionowany, konwencjonalny podział prawnokarnych wskazań kształtujących sądowy wymiar kary na: zasady, dyrektywy oraz okoliczności wpływające na wspomniany proces, wypadałoby w pierwszej kolejności stwierdzić, że „odpowiednim” stosowaniem w świetle ustawy o izbach lekarskich zostały objęte de facto dwie zasady wymiaru kary - tj. zasada humanitaryzmu oraz zasada względnej swobody sądu. Istotę wspomnianej zasady humanitaryzmu oddaje treść art. 3 k.k., z którego postanowień wynika, że środki reakcji prawnokarnej powinny być stosowane z uwzględnieniem zasad humanitaryzmu, w szczególności z poszanowaniem godności człowieka. $\mathrm{W}$ treści niniejszej zasady wyrażony został $\mathrm{w}$ istocie postulat minimalizowania cierpień oraz innych dolegliwości, jakie wiążą się ze stosowaniem wszelkich form reakcji karnoprawnej ${ }^{39}$. Oceniając znaczenie wspomnianej zasady na płasz-

\footnotetext{
${ }^{37}$ Postanowienie Sądu Najwyższego z dnia 8 maja 2014 r., sygn. akt SDI 12/14, Legalis nr 1024796.

38 Tamże. Jak wskazano w niniejszym judykacie, uchybienia te nie mogą jednak naruszać pewnych minimalnych standardów w zakresie stosowania przepisów karnoprawnych.

${ }^{39}$ Postanowienie Sądu Apelacyjnego we Wrocławiu z dnia 27 kwietnia 2016 r., sygn. akt II AKz 139/16, LEX nr 2080914; postanowienie Sądu Najwyższego z dnia 19 października 2010 r., sygn. akt II KK 224/10, LEX nr 844423.
} 
czyźnie odpowiedzialności zawodowej lekarzy, można by - przynajmniej prima facie - wysunąć pogląd, że w tym zakresie nie odgrywa ona znaczącej roli. Do wysunięcia takiego wniosku skłania - jak się wydaje - specyfika wspomnianego rodzaju odpowiedzialności, a zwłaszcza brak możliwości orzekania w jej ramach kar ograniczających czy też pozbawiających wolności ${ }^{40}$. Zaprezentowany tutaj punkt widzenia mógłby jednak niekiedy rodzić pewne wątpliwości. Trudno bowiem nie zauważyć, że kary, które mogą zostać orzeczone wobec członków izb lekarskich, różnią się pod względem swej dolegliwości oraz towarzyszących im następstw. Z tego też względu wydaje się, że nie sposób pominąć znaczenia „odpowiedniego” stosowania karnoprawnej zasady humanitaryzmu zwłaszcza w przypadku, gdy sąd lekarski decyduje o zastosowaniu kary najdalej ingerującej w sferę praw jednostki, w postaci zawieszenia czy pozbawienia prawa wykonywania zawodu ${ }^{41}$.

Z kolei druga z wyróżnionych zasad, tj. zasada względnej swobody sądu, akcentuje pewną sferę dyskrecjonalności sądu lekarskiego w procesie orzekania kary. Wykorzystując również tutaj karnistyczną interpretację zasady swobodnego uznania sędziowskiego, o której mowa w art. $53 \S 1$ k.k., należy stwierdzić, że zasada ta nie kreuje dowolności w omawianym procesie ${ }^{42}$, skoro powinnością sądu jest wymierzanie tylko takich kar, jakie zostały przewidziane w ustawie, przy uwzględnieniu normatywnie przewidzianych wskazań, mających znaczenie dla

${ }^{40}$ KozIK, Odpowiedzialność zawodowa lekarzy, s. 25. Wyrażony pogląd koresponduje przy tym $\mathrm{z}$ wypowiedzią prezentowaną także $\mathrm{w}$ doktrynie karnistycznej, w której przekonywano o de facto symbolicznej roli wspomnianej zasady, skoro w istocie polskie prawo nie przewiduje obecnie sankcji, które można by (mając na względzie doświadczenia z przeszłości) uznać za niehumanitarne, zob. T. Bojarski, Polskie prawo karne. Zarys części ogólnej, Warszawa: LexisNexis 2012, s. 477; TENże, Uwagi o dalszych projektowanych zmianach części ogólnej kodeksu karnego, [w:] Nowe prawo karne po zmianach, red. T. Bojarski, E. Skrętowicz, Lublin: Wydawnictwo UMCS 2002, s. 62.

${ }^{41} \mathrm{~W}$ orzecznictwie podkreśla się przy tym, iż dla osób wykonujących zawody zaufania publicznego każda w istocie kara jest dolegliwa, gdyż jej orzeczenie powoduje utratę zaufania publicznego, wpływa na dalsze relacje $\mathrm{z}$ pacjentami, a niekiedy dyskredytuje w oczach opinii publicznej. Zob. wyrok Trybunału Konstytucyjnego z dnia 29 czerwca 2010 r., sygn. akt P 28/09, LEX nr 602879; zob. również wyrok Trybunału Konstytucyjnego z dnia 18 października 2010, sygn. akt K 1/09, OTK-A 2010, nr 8, poz. 76, w którym wskazano, iż dożywotnie pozbawienie prawa wykonywania zawodu stanowi rozwiązanie niezgodne z przepisami ustawy zasadniczej. Warto również nadmienić, iż obowiązujący katalog kar orzekanych tytułem odpowiedzialności zawodowej jest w istocie rozbudowany, co również koreluje z założeniami zasady humanitaryzmu. Zob. na zgłaszane w tym zakresie uwagi w kontekście regulacji karnoprawnych: A. SAKowicz, Sankcja bezwzględnie oznaczona (uwagi krytyczne na tle art. 148 \& 2 k.k.), „Państwo i Prawo” 5 (2006), s. 18; E. ŁęTowskA, Kara za zabójstwo kwalifikowane - problematyka konstytucyjna, „Państwo i Prawo” 10 (2006), s. 5.

${ }^{42} \mathrm{Na}$ płaszczyźnie rozwiązań karnoprawnych przyjmuj się, że: „Wykładnikiem granic «uznaniowości» sądu jest wskazana w przepisie art. 438 pkt 4 k.p.k. rażąca niewspółmierność kary", zob. wyrok Sądu Apelacyjnego w Katowicach z dnia 28 lutego 2013 r., sygn. akt II AKa 550/12, LEX nr 1294787; wyrok Sądu Najwyższego z dnia 22 marca 2012 r., sygn. akt IV KK 322/11, OSNKW 2012, nr 9, poz. 94. 
prawidłowego doboru określonej sankcji ${ }^{43}$. W orzecznictwie stwierdza się wprost, że sędziowskie uznanie: „[...] nie może być uznaniem dowolnym”44, a zatem abstrahującym od rozważenia szeregu czynników.

„Odpowiednim” stosowaniem na gruncie ustawy o izbach lekarskich zostały objęte ponadto cztery ogólne dyrektywy sądowego wymiaru ${ }^{45}$, wynikające z treści art. $53 \S 1$ k.k. oraz jedna dyrektywa szczególna, o której mowa w art. $53 \S 3$ k.k. Nie tracąc $\mathrm{z}$ pola widzenia przedstawionej $\mathrm{w}$ ostatnim czasie propozycji zmian $\mathrm{w}$ tym zakresie $^{46}$, należy podkreślić, że aktualnie katalog ogólnych dyrektyw sądowego

${ }^{43}$ Zob. wyrok Sądu Apelacyjnego w Gdańsku z dnia 4 lutego 2015 r., sygn. akt II AKa 425/14, LEX nr 1953157, w którym stwierdzono: „Wynikająca z przepisu art. 53 k.k. zasada swobodnego uznania sądu co do rodzaju i rozmiaru środków represji karnej nie oznacza dowolności, gdyż sąd powinien stosować dyrektywy wymiaru kary oraz brać pod uwagę okoliczności mające znaczenie dla wymiaru kary". Sąd orzekający jest wprawdzie uprawniony do wymierzania kary wedle swego uznania, niemniej może to uczynić jedynie w granicach przewidzianych przez ustawę. Zob. także wyrok Sądu Apelacyjnego w Szczecinie z dnia 4 grudnia 2014 r., sygn. akt II AKa 148/14, LEX nr 1668659.

${ }^{44}$ Wyrok Sądu Apelacyjnego w Warszawie z dnia 30 stycznia 2013 r., sygn. akt II AKa 263/12, LEX nr 1283404.

${ }^{45}$ Zob. wyrok Sądu Najwyższego z dnia 7 lutego 2014 r., sygn. akt SDI 52/13, Legalis nr 768704, w którym wskazano: „Przy orzekaniu w postępowaniu odwoławczym Naczelny Sąd Lekarski powinien - zachowując pełną samodzielność jurysdykcyjną (art. 8 k.p.k.) - prawidłowo uwzględnić obowiązującą regulację ustawową odnoszącą się do wszystkich dyrektyw wymiaru kary i rozważyć orzeczenie kary dyscyplinarnej w takiej postaci, która byłaby zarówno współmierna do stopnia zawinienia i ustalonych okoliczności obciążających oraz łagodzących, jak i stanowiła realną dolegliwość dla obwinionego, realizującą wymogi indywidualnego oddziaływania, a także funkcje kary przewidziane w ramach prewencji generalnej".

${ }^{46}$ Zgodnie z projektem, dostępnym na stronie internetowej Ministerstwa Sprawiedliwości, art. $53 \S 1$ k.k. ma otrzymać następujące brzmienie: „§ 1. Sąd wymierza karę według swojego uznania, $\mathrm{w}$ granicach przewidzianych w ustawie, uwzględniając stopień społecznej szkodliwości czynu, okoliczności obciążające i okoliczności łagodzące, cele kary w zakresie społecznego oddziaływania, a także cele zapobiegawcze, które ma ona osiągnąć w stosunku do skazanego. Dolegliwość kary nie może przekraczać stopnia winy". Poza tym w projekcie przewiduje się, że po $§ 2$ ma zostać dodany § 2a-2c w brzmieniu: „§ 2a. Okoliczności obciążające stanowią w szczególności: 1) uprzednia karalność za przestępstwo umyślne lub podobne przestępstwo nieumyślne; 2) bezprawne wpływanie na treść zeznań lub oświadczeń pokrzywdzonego, zeznań świadków lub opinii biegłych, lub treść wyjaśnień innych oskarżonych; 3) wykorzystanie bezradności, niepełnosprawności, choroby lub podeszłego wieku pokrzywdzonego; 4) sposób działania, prowadzący do poniżenia lub udręczenia pokrzywdzonego; 5) popełnienie przestępstwa $z$ premedytacją; 6) popełnienie przestępstwa $z$ motywacją zasługującą na szczególne potępienie lub z niskich pobudek; 7) popełnienie z użyciem przemocy przestępstwa motywowanego nienawiścią z powodu przynależności narodowej, etnicznej, rasowej, politycznej lub wyznaniowej ofiary albo z powodu jej bezwyznaniowości; 8) działanie ze szczególnym okrucieństwem; 9) popełnienie przestępstwa w stanie po spożyciu alkoholu lub środka odurzającego, jeżeli stan ten był czynnikiem prowadzącym do popełnienia przestępstwa lub istotnego zwiększenia jego skutków; 10) popełnienie przestępstwa we współdziałaniu z małoletnim lub z wykorzystaniem jego udziału. § 2b. Okoliczności łagodzące stanowią w szczególności: 1) działanie z pobudek zasługujących na uwzględnienie; 2) popełnienie przestępstwa pod wpływem gniewu, strachu lub wzburzenia, 
wymiaru kary tworzą dyrektywy: stopnia winy, stopnia społecznej szkodliwości czynu, prewencji szczególnej oraz prewencji ogólnej. Zgodnie zaś z utrwalonym poglądem prezentowanym w doktrynie karnistycznej, wymiar kary jest ksztaltowany w ten sposób, że górną granicę limituje stopień winy ${ }^{47}$, zaś dolną wyznaczają potrzeby prewencji ogólnej ${ }^{48}$. W kontekście powyższego ujęcia wypada więc podkreślić, że cele ogólnoprewencyjne nie uzasadniają wymierzenia kary powyżej stopnia winy sprawcy ${ }^{49}$, co w istocie miałoby na celu odstraszenie innych osób. „Odpowiednie” stosowanie art. $53 \S 1$ k.k. in fine na płaszczyźnie ustawy o izbach lekarskich nie może zatem bazować na idei tzw. negatywnej prewencji ogólnej, która skuteczność sankcji wiązała de facto z jej surowością. Założenie to prowadziłoby do przedmiotowego czy też inaczej instrumentalnego traktowania obwinionego. Stąd też „współczesne” ujęcie dyrektywy ogólnoprewencyjnej (aprobowane również na płaszczyźnie odpowiedzialności zawodowej lekarzy) określanej mianem

usprawiedliwionych okolicznościami zdarzenia; 3) działanie pod wpływem osoby, wobec której sprawca pozostawał w stosunku zależności; 4) popełnienie przestępstwa w reakcji na nagłą sytuację, której prawidłowa ocena była istotnie utrudniona $\mathrm{z}$ uwagi na okoliczności osobiste, zakres wiedzy lub doświadczenia życiowego sprawcy; 5) działanie pod wpływem szczególnie ciężkich warunków osobistych; 6) dobrowolne podjęcie działań zmierzających do zapobieżenia szkodzie lub krzywdzie, wynikającej z przestępstwa, albo ograniczenia jej rozmiaru; 7) skuteczne skłonienie osób współdziałających do odstąpienia od czynu zabronionego lub podjęcia działań zapobiegających powstaniu szkody lub służących ograniczeniu jej rozmiaru; 8) dobrowolne naprawienie szkody wyrządzonej przestępstwem; 9) dobrowolne zadośćuczynienie pokrzywdzonemu; 10) dobrowolne ujawnienie popełnionego przez siebie przestępstwa organowi powołanemu do ścigania przestępstw. § 2c. Nie stanowi okoliczności, o której mowa w $§ 2 \mathrm{a}$ i $\S 2 \mathrm{~b}$ okoliczność stanowiąca znamię przestępstwa, które popełnił sprawca, chyba że wystąpiła ona ze szczególnie wysokim albo ze szczególnie niskim nasileniem", zob. Projekt ustawy o zmianie ustawy - Kodeks karny oraz niektórych innych ustaw, [w:] https: //legislacja.rcl.gov.pl/docs//2/12320403/12565603/12565604/dokument378684.pdf [dostęp: 2.02.2019].

47 Zob. wyrok Sądu Apelacyjnego w Łodzi z dnia 27 września 2012 r., sygn. akt II AKa 83/12, LEX nr 1220567, w którym wskazano: „[...] sąd powinien baczyć przede wszystkim na to, aby dolegliwość całokształtu represji nie przekraczała stopnia jego winy, albowiem każda kara niespełniająca tego ostatniego wymogu uznana będzie za rażąco surową [...]”. „«Wina» sprawcy przestępstwa w konkretnym stanie faktycznym jest wyznaczana zarówno przez ocenę społecznej szkodliwości popełnionego czynu, jak również rzutowany na tę ocenę stopień zawinienia; tym samym, przy ustalaniu «stopnia winy», w rozumieniu art. 53 k.k., należy uwzględniać także ocenę stopnia społecznej szkodliwości popełnionego czynu”. Zob. również wyrok Sądu Apelacyjnego w Lublinie z dnia 27 października 2015 r., sygn. akt II AKa 242/15, LEX nr 1950204.

${ }^{48}$ Wyrok Sądu Apelacyjnego w Krakowie z dnia 24 października 2002 r., sygn. akt II AKa 258/02, „Krakowskie Zeszyty Sądowe” 2002, nr 10, poz. 52; wyrok Sądu Apelacyjnego w Poznaniu z dnia 30 sierpnia 2012 r., sygn. akt II AKa 142/12, LEX nr 1307467; wyrok Sądu Apelacyjnego w Łodzi z dnia 15 września 2015 r., sygn. akt II AKa 98/15, LEX nr 1814813.

${ }^{49}$ Wyrok Sądu Apelacyjnego w Krakowie z dnia 23 listopada 2000 r., sygn. akt II AKa 147/00, „Krakowskie Zeszyty Sądowe” 2001, nr 1, poz. 24. 
tzw. pozytywnej prewencji ogólnej ${ }^{50} \mathrm{ma}-\mathrm{w}$ myśl intencji twórców obowiązującego Kodeksu karnego - gwarantować m.in. orzekanie takich kar, które będą odbierane przez społeczeństwo jako sprawiedliwa reakcja ${ }^{51}$. Jednocześnie wskazuje się, że sankcja realizująca wspomniany cel ogólnoprewencyjny nie może być oczywiście: „[...] niższa od stopnia tolerancji, poniżej którego powstaje przekonanie, że chronione normą wartości nie znajdują w rzeczywistości ochrony, ze względu na zbyt liberalne traktowanie" ${ }^{\$ 2}$ osób, uchybiających określonym przepisom prawa ${ }^{53}$.

Katalog omawianych tutaj ogólnych dyrektyw uzupełnia dyrektywa stopnia społecznej szkodliwości czynu, która w istocie wymaga dokonania łącznej oceny czynu, odnoszącej się do jego elementów przedmiotowych (rodzaju i charakteru naruszonego dobra, rozmiaru wyrządzonej szkody, sposobu i okoliczności popełnienia czynu) oraz podmiotowych (rodzaju zamiaru, motywów obwinionego) ${ }^{54}$. Ustalenie samego „stopnia” społecznej szkodliwości czynu, który może w kontekście rozważanej odpowiedzialności zawodowej sięgać nawet poziomu znikomego, subminimalnego, rzutuje niewątpliwie na finalny dóbr sankcji ${ }^{55}$. Klauzulą „odpowiedniego" stosowania na gruncie ustawy o izbach lekarskich została objęta także dyrektywa prewencji indywidualnej, która w art. $53 \S 1$ k.k. odwołuje się do osiągnięcia (za pośrednictwem orzekanej kary) celów zapobiegawczych oraz wychowawczych. Tym samym należałoby stwierdzić, że o ile pierwszy z wymienionych celów, na gruncie odpowiedzialności zawodowej lekarzy, wymagałby zastanowienia się nad wskazaniem właściwych mechanizmów przeciwdziałających ponownemu popełnieniu przewinienia przez obwinionego, o tyle realizacja celu wychowawczego wiązałaby się z ideą kształtowania właściwej postawy, a także

50 „Prewencja ogólna może być rozumiana na gruncie Kodeksu karnego tylko w znaczeniu pozytywnym, jako działanie za pomocą kary i innych środków w kierunku kształtowania w świadomości społecznej przekonania o obowiązywaniu danej normy prawnej i jej rzeczywistej ochronie w procesie wymiaru sprawiedliwości”, zob. wyrok Sądu Apelacyjnego w Łodzi z dnia 31 lipca 2014 r., sygn. akt II AKa 143/14, LEX nr 1506222; wyrok Sądu Apelacyjnego w Gdańsku z dnia 15 października 2014 r., sygn. akt II AKa 354/14, LEX nr 1668566.

${ }^{51}$ Nowe kodeksy karne z uzasadnieniem, Warszawa: Wydawnictwo Prawnicze 1997, s. 153.

${ }^{52}$ A. ZolL, Założenia polityki karnej w projekcie kodeksu karnego, „Państwo i Prawo” 5 (1994), s. 7.

${ }^{53}$ Zob. także wyrok Sądu Apelacyjnego w Gdańsku z dnia16 grudnia 2015 r., sygn. akt II AKa 365/15, LEX nr 2031191; wyrok Sądu Apelacyjnego we Wrocławiu z dnia 13 marca 2003 r., sygn. akt II AKa 47/03, „Krakowskie Zeszyty Sądowe” 2003, nr 12, poz. 30.

${ }^{54}$ Wyrok Sądu Apelacyjnego w Szczecinie z dnia 4 grudnia 2014 r., sygn. akt II AKa 148/14, LEX nr 1668659.

${ }^{55}$ Postanowienie Sądu Najwyższego z dnia 10 czerwca 2003 r., sygn. akt II KK 87/03, LEX nr 78371. 
ze wzbudzeniem u obwinionego krytycznej autorefleksji wobec własnego czynu ${ }^{56}$, co wydaje się znacznie trudniejszym zadaniem.

Mając na uwadze zaprezentowane powyżej ogólne dyrektywy, należałoby również zaznaczyć, że stricte „dopełniający” charakter w stosunku do ich postanowień ${ }^{57}$ posiadają kodeksowe okoliczności, wymienione w art. $53 \S 2$ k.k. ${ }^{58}$ Ich „odpowiednie” uwzględnienie na gruncie odpowiedzialności zawodowej członków izb lekarskich powinno de facto ułatwiać prawidłową orientację co do racjonalności zastosowania określonej kary ${ }^{59}$.

Ostatnią zaś z prawnokarnych regulacji, która - wprawdzie w niektórych - przypadkach mogłaby znaleźć „odpowiednie” zastosowanie przy doborze kary wobec członków izb lekarskich jest szczególna dyrektywa (art. 53 § 3 k.k.), która verba legis nawiązuje do roli, jaką na tym etapie postępowania mogą odgrywać rezultaty jednej z tzw. alternatywnych metod rozwiązywania konfliktów, czyli mediacji. Do instytucji tej odwołuje się zresztą rozdział VI ustawy o izbach lekarskich. Rezultat, w postaci osiągnięcia „pozytywnych wyników mediacji” może w istocie łagodząco wpłynąć na decyzję o rodzaju zastosowanej wobec obwinionego sankcji, co jednak nie zawsze musi nastąpić. Wypada bowiem podkreślić, że wprawdzie podjęcie starań mediacyjnych stanowi okoliczność przemawiającą na korzyść obwinionego, to jednak nie sposób pominąć, iż sam proces doboru kary stanowi de facto wypadkową bardzo wielu czynników, wymagających wszechstronnej analizy.

Zaprezentowany powyżej katalog prawnokarnych wskazań, które powinny znaleźć „odpowiednie” zastosowanie przy orzekaniu kary wobec członków izb lekarskich nie wyczerpuje przedmiotowej materii. Na odrębną uwagę zasługuje bowiem regulacja, zawarta w art. 83 ustawy o izbach lekarskich, z której wynika zasada stopniowalności kar, jak również rozwiązanie przewidziane w art. 83 ust. 2 cytowanej ustawy, wyrażające zasadę dopuszczalnej kumulacji stosowanych kar ${ }^{60}$.

${ }^{56}$ Wyrok Sądu Okręgowego w Olsztynie z dnia 12 września 2013 r., sygn. akt II K 106/13, LEX nr 1715729.

${ }^{57}$ A. MAReK, Kodeks karny. Komentarz, Warszawa: Wolters Kluwer 2007, s. 143.

${ }^{58} \mathrm{~W}$ piśmiennictwie oraz orzecznictwie karnistycznym wymienia się jako przykłady pozakodeksowych okoliczności m.in. przyznanie się do popełnionego czynu oraz - z pewnym jednak zastrzeżeniami - nagminność popełniania określonego rodzaju przestępstw. Zob. wyrok Sądu Apelacyjnego w Krakowie z dnia 24 czerwca 2009 r., sygn. akt II AKa 116/09, „Krakowskie Zeszyty Sądowe” 2009, nr 7-8, poz. 56; wyrok Sądu Apelacyjnego w Lublinie z dnia 16 lutego 2010 r., sygn. akt II AKa 7/10, „Krakowskie Zeszyty Sądowe” 2010, nr 7-8, poz. 54.

${ }^{59}$ K. Maksymowicz, T. Szewiola, Okoliczności obciążające w ujęciu teorii i orzecznictwa Sąu Najwyższego, „Nowe Prawo” 3-4 (1982), s. 54-55.

${ }^{60}$ Zgodnie z tym ostatnim przepisem, orzeczenie kary ograniczenia zakresu czynności w wykonywaniu zawodu lekarza na okres od sześciu miesięcy do dwóch lat czy zawieszenie prawa wykonywania zawodu na okres od roku do pięciu lat może łączyć się z orzeczeniem kary w postaci 
Ponadto, trzeba także wspomnieć, że katalog kar, określony w art. 83 ust. 1 ustawy o izbach lekarskich ma charakter zamknięty ${ }^{61}$, co w konsekwencji potwierdza akceptację innej zasady - tj. zasady oznaczoności stosowanych kar $^{62}$. Poza tym należy także w tym miejscu nadmienić, że dla procesu orzekania kary wobec członków izb lekarskich nie bez znaczenia pozostają zasady ogólnoustrojowe, wynikające wprost z przepisów Konstytucji RP (zasada poszanowania przyrodzonej i niezbywalnej godności człowieka - art. 30, zasada wprowadzająca zakaz stosowania tortur oraz okrutnego traktowania - art. 40, zasada równości - art. 32 ust. 1, jak również zasadę proporcjonalności - art. 31 ust. 3).

\section{UWAGI KOŃCOWE}

W przeprowadzonych analizach starano się wykazać, że ogólnie wysoka w hierarchii społecznej pozycja zawodu lekarza implikuje równie wysokie wymagania, jakie kierowane są wobec przedstawicieli wspomnianego zawodu zaufania publicznego. Oczekiwania te z oczywistych względów dotyczą nie tylko merytorycznych kompetencji, ale również odnoszą się do posiadania określonych predyspozycji osobowościowych $^{63} . \mathrm{Z}$ dokonanych ustaleń wynika, że ciążące na lekarzach obowiązki wyznaczają nie tylko normy prawne, ale również normy etyczne, związane $\mathrm{z}$ tradycją tego zawodu. Uchybienia wskazanym normom skutkuje zaś ujemnymi konsekwencjami, związanymi m.in. z ponoszeniem odpowiedzialności zawodowej. Z uwagi na charakter tego rodzaju odpowiedzialności należy zaznaczyć, że zarówno samo zakwalifikowanie określonego zachowania jako przewinienia zawodowego, jak również ewentualny dobór kary nie powinny opierać się na dowolności organów orzekających, lecz znajdować poparcie w rzetelnie zebranym

zakazu pełnienia funkcji kierowniczych w jednostkach organizacyjnych ochrony zdrowia na okres od roku do pięciu lat.

${ }^{61}$ Trafnie odnotowuje się, że o ile fundamentalna zasada prawa karnego nullum crimen sine lege nie znajduje odzwierciedlenia na płaszczyźnie odpowiedzialności zawodowej lekarzy, o tyle zasada nulla poena sine lege obowiązuje w tym zakresie w pełnym wymiarze. Zob. E. ZieLIŃsKA, Odpowiedzialność zawodowa lekarza i jej stosunek do odpowiedzialności karnej, Warszawa: Liber 2001, s. 161.

${ }^{62}$ R. Kubiak, Tajemnica medyczna, Warszawa: C.H. Beck 2015, s. 107 n. Wydaje się również, że katalog rozważanych tutaj zasad, współkształtujących prawidłowy dobór kary, uzupełnia zasada indywidualizacji, która wymaga, aby proces wyboru i miarkowania właściwej formy reakcji był zorientowany na konkretnego obwinionego. Na temat istoty tej zasady zob. m.in. wyrok Sądu Apelacyjnego w Białymstoku z dnia 28 stycznia 2014 r., sygn. akt II AKa 268/13, LEX nr 1437862.

${ }^{63}$ E. WILCZEK-RuŻYCZKA, Wypalenie zawodowe pracowników medycznych, Warszawa: Wolters Kluwer 2014, s. 81. 
materiale dowodowym. Taka postawa sądów lekarskich może bowiem przyczynić się do zmniejszenia - przynajmniej w niektórych kwestiach - tradycyjnie wysuwanych wątpliwości natury gwarancyjnej, które pojawiają się nieuchronnie przy egzekwowaniu odpowiedzialności zawodowej ${ }^{64}$.

\section{BIBLIOGRAFIA}

\section{ŹRÓDŁA PRAWA}

Konstytucja Rzeczypospolitej Polski z dnia 2 kwietnia 1997 r., Dz. U. Nr 78, poz. 483 z późn. zm. Ustawa z dnia 18 lipca 1950 r. o odpowiedzialności zawodowej fachowych pracowników służby zdrowia, Dz. U. Nr 36, poz. 332 z późn. zm.

Ustawa z dnia 19 kwietnia 1991 r. o izbach aptekarskich, Dz. U. z 2016 r., poz. 1496 z późn. zm.

Ustawa z dnia 19 sierpnia 1994 r. o ochronie zdrowia psychicznego, Dz. U. z 2018 r., poz. 1878 z późn. zm.

Ustawa z dnia 5 grudnia 1996 r. o zawodach lekarza i lekarza dentysty, Dz. U. z 2018 r., poz. 617 z późn. zm.

Ustawa z dnia 6 czerwca 1997 r. Kodeks karny, Dz. U. z 2018 r., poz. 1600 z późn. zm.

Ustawa z dnia 6 listopada 2008 r. o prawach pacjenta i Rzeczniku Praw Pacjenta, Dz. U. z 2017 r., poz. $1318 \mathrm{z}$ późn. zm.

Ustawa z dnia 2 grudnia 2009 r. o izbach lekarskich, Dz. U. z 2018 r., poz. 168 z późn. zm.

Ustawa z dnia 15 kwietnia 2011 r. o działalności leczniczej, Dz. U. z 2018 r., poz. 2190 z późn. zm.

Ustawa z dnia 1 lipca 2011 r. o samorządzie pielęgniarek i położnych, Dz. U. z 2018 r., poz. 916 z późn. zm.

Rozporządzenie Prezesa Rady Ministrów z dnia 20 czerwca 2002 r. w sprawie „Zasad techniki prawodawczej”, Dz.U. z 2016 r., poz. 283 z późn. zm.

\section{ORZECZNICTWO}

Uchwała Trybunału Konstytucyjnego z dnia 17 marca 1993 r., sygn. akt W 16/92, OTK 1993, poz. 16. Wyrok Trybunału Konstytucyjnego z dnia 1 grudnia 1998 r., sygn. akt K 21/98, OTK 1998, nr 7, poz. 116 Wyrok Trybunału Konstytucyjnego z dnia 11 stycznia 2000 r., sygn. akt K 7/99, OTK 2000, nr 1, poz. 2. Wyrok Trybunału Konstytucyjnego z dnia 28 czerwca 2000 r., sygn. akt K 25/99, OTK 2000, nr 5, poz. 141.

Wyrok Trybunału Konstytucyjnego z dnia 27 lutego 2001 r., sygn. akt K 22/00, OTK 2001, nr 3 , poz. 48.

Wyrok Trybunału Konstytucyjnego z dnia 12 lipca 2001 r., sygn. akt SK 1/01, OTK 2001, nr 5, poz. 127. Wyrok Trybunału Konstytucyjnego z dnia 7 maja 2002 r., sygn. akt SK 20/00, OTK-A 2002, nr 3, poz. 29.

${ }^{64} \mathrm{Na}$ temat jeszcze innych wątpliwości, związanych ze stosowaniem przepisów niniejszej ustawy w zakresie odpowiedzialności zawodowej zob. m.in. P. KoniECZNiaK, O pewnych problemach szczególnych $w$ stosowaniu rozdziału 5 ustawy o izbach lekarskich (odpowiedzialność zawodowa), „Prawo i Medycyna” 3-4 (2014), s. 130 n. 
Wyrok Trybunału Konstytucyjnego z dnia 18 lutego 2004 r., sygn. akt P 21/02, OTK-A 2004, nr 2, poz. 9.

Wyrok Trybunału Konstytucyjnego z dnia 29 czerwca 2006 r., sygn. akt P 30/05, OTK-A 2006, nr 6, poz. 70 .

Wyrok Trybunału Konstytucyjnego z dnia 27 listopada 2006 r., sygn. akt K 47/04, OTK-A 2006, nr 10, poz. 153.

Wyrok Trybunału Konstytucyjnego z dnia 2 lipca 2007 r., sygn. akt K 41/05, OTK-A 2007, nr 7 , poz. 72 .

Wyrok Trybunału Konstytucyjnego z dnia 23 kwietnia 2008 r., sygn. akt SK 16/07, OTK-A 2008, nr 3, poz. 45.

Wyrok Trybunału Konstytucyjnego z dnia 29 czerwca 2010 r., sygn. akt P 28/09, LEX nr 602879.

Wyrok Trybunału Konstytucyjnego z dnia 18 października 2010, sygn. akt K 1/09, OTK-A 2010, nr 8, poz. 76.

Postanowienie Trybunału Konstytucyjnego z dnia 7 października 1992 r., sygn. akt U 1/92, OTK 1992, nr 2, poz. 38.

Uchwała Sądu Najwyższego z dnia 6 grudnia 2000 r., sygn. akt III CZP 41/00, OSNC 2001, nr 4, poz. 57.

Uchwała Sądu Najwyższego z dnia 30 stycznia 2001 r., sygn. akt I KZP 50/00, OSNKW 2001, nr 3-4, poz. 16.

Wyrok Sądu Najwyższego z dnia 18 lutego 1994 r., sygn. akt I PLN 1/94, Legalis nr 28453.

Wyrok Sądu Najwyższego z dnia 29 października 2009 r., sygn. akt SDI 22/09, Legalis nr 303967.

Wyrok Sądu Najwyższego z dnia 22 marca 2012 r., sygn. akt IV KK 322/11, OSNKW 2012, nr 9, poz. 94.

Wyrok Sądu Najwyższego z dnia 7 lutego 2014 r., sygn. akt SDI 52/13, Legalis nr 768704.

Postanowienie Sądu Najwyższego z dnia 10 czerwca 2003 r., sygn. akt II KK 87/03, LEX nr 78371.

Postanowienie Sądu Najwyższego z dnia 19 października 2010 r., sygn. akt II KK 224/10, LEX nr 844423.

Postanowienie Sądu Najwyższego z dnia 8 maja 2014 r., sygn. akt SDI 12/14, Legalis nr 1024796.

Postanowienie Sądu Najwyższego z dnia 11 lutego 2016 r., sygn. akt SDI 70/15, Legalis nr 1430517.

Postanowienie Sądu Najwyższego z dnia 11 lutego 2016 r., sygn. akt SDI 71/15, OSNKW 2016, nr 5, poz. 34.

Wyrok Sądu Apelacyjnego w Krakowie z dnia 23 listopada 2000 r., sygn. akt II AKa 147/00, Krakowskie Zeszyty Sądowe 2001, nr 1, poz. 24.

Wyrok Sądu Apelacyjnego w Krakowie z dnia 24 października 2002 r., sygn. akt II AKa 258/02, Krakowskie Zeszyty Sadowe 2002, nr 10, poz. 52.

Wyrok Sądu Apelacyjnego we Wrocławiu z dnia 13 marca 2003 r., sygn. akt II AKa 47/03, Krakowskie Zeszyty Sądowe 2003, nr 12, poz. 30.

Wyrok Sądu Apelacyjnego w Krakowie z dnia 24 czerwca 2009 r., sygn. akt II AKa 116/09, Krakowskie Zeszyty Sąowe 2009, nr 7-8, poz. 56.

Wyrok Sądu Apelacyjnego w Lublinie z dnia 16 lutego 2010 r., sygn. akt II AKa 7/10, Krakowskie Zeszyty Saqdowe 2010, nr 7-8, poz. 54.

Wyrok Sądu Apelacyjnego w Poznaniu z dnia 30 sierpnia 2012 r., sygn. akt II AKa 142/12, LEX nr 1307467.

Wyrok Sądu Apelacyjnego w Łodzi z dnia 27 września 2012 r., sygn. akt II AKa 83/12, LEX nr 1220567. 
Wyrok Sądu Apelacyjnego w Warszawie z dnia 30 stycznia 2013 r., sygn. akt II AKa 263/12, LEX nr 1283404.

Wyrok Sądu Apelacyjnego w Katowicach z dnia 28 lutego 2013 r., sygn. akt II AKa 550/12, LEX nr 1294787.

Wyrok Sądu Apelacyjnego w Białymstoku z dnia 28 stycznia 2014 r., sygn. akt II AKa 268/13, LEX nr 1437862.

Wyrok Sądu Apelacyjnego w Lodzi z dnia 31 lipca 2014 r., sygn. akt II AKa 143/14, LEX nr 1506222.

Wyrok Sądu Apelacyjnego w Gdańsku z dnia 15 października 2014 r., sygn. akt II AKa 354/14, LEX nr 1668566.

Wyrok Sądu Apelacyjnego w Szczecinie z dnia 4 grudnia 2014 r., sygn. akt II AKa 148/14, LEX nr 1668659.

Wyrok Sądu Apelacyjnego w Gdańsku z dnia 4 lutego 2015 r., sygn. akt II AKa 425/14, LEX nr 1953157.

Wyrok Sądu Apelacyjnego w Łodzi z dnia 15 września 2015 r., sygn. akt II AKa 98/15, LEX nr 1814813. Wyrok Sądu Apelacyjnego w Lublinie z dnia 27 października 2015 r., sygn. akt II AKa 242/15, LEX nr 1950204.

Wyrok Sądu Apelacyjnego w Gdańsku z dnia 16 grudnia 2015 r., sygn. akt II AKa 365/15, LEX nr 2031191.

Postanowienie Sądu Apelacyjnego we Wrocławiu z dnia 27 kwietnia 2016 r., sygn. akt II AKz 139/16, LEX nr 2080914.

Wyrok Sądu Okręgowego w Olsztynie z dnia 12 września 2013 r., sygn. akt II K 106/13, LEX nr 1715729.

\section{LITERATURA}

BANASIŃSKi Cezary: Samorząd gospodarczy i samorząd zawodowy, [w:] Prawo gospodarcze. Zagadnienia administracyjnoprawne, red. H. Gronkiewicz-Waltz, M. Wierzbowski, Warszawa: Wolters Kluwer 2011, s. 180-199.

BoJARSKi Tadeusz: Polskie prawo karne. Zarys części ogólnej, Warszawa: LexisNexis 2012.

BoJARSKI Tadeusz: Uwagi o dalszych projektowanych zmianach części ogólnej kodeksu karnego, [w:] Nowe prawo karne po zmianach, red. T. Bojarski, E. Skrętowicz, Lublin: Wydawnictwo UMCS 2002, s. 59-68.

BoseK Leszek: Etyka lekarska, [w:] Prawo wobec medycyny i biotechnologii. Zbiór orzeczeń z komentarzami, red. M. Safjan, Warszawa: Wolters Kluwer 2011, s. 27-30.

BrzozowsKa-KruczeK Małgorzata: Zawody medyczne, Warszawa: Wolters Kluwer 2013.

DomaŃSKi Henryk, SAwiński Zbigniew, SŁomczyński Kazimierz M.: Prestiż zawodów w obliczu zmian społecznych: 1958-2008, Studia Socjologiczne 4 (2010), s. 79-119.

FiutaK Agnieszka: Prawo w medycynie, Warszawa: C.H. Beck 2011.

GiĘTKOwski Radosław: Odpowiedzialność dyscyplinarna w prawie polskim, Gdańsk: Wydawnictwo Uniwersytetu Gdańskiego 2013.

Grzonka Lesław, Kosturbiec Jarosław: Zawód zaufania publicznego. Przyczynek do dyskusji, Studia Iuridica Lublinensia t. IX (2007), s. 25-34.

HAUSER Maria: Odpowiednie stosowanie przepisów prawa - uwagi porządkujące, Acta Universitatis Wratislaviensis t. LXV (2005), s. 151-168.

KARKOWSKa Dorota: Prawo medyczne dla pielęgniarek, Warszawa: Wolters Kluwer 2013.

KARKOwSKA Dorota: Zawody medyczne, Warszawa: Wolters Kluwer 2012. 
KonieCZNiaK Przemysław: O pewnych problemach szczególnych w stosowaniu rozdziału 5 ustawy o izbach lekarskich (odpowiedzialność zawodowa), Prawo i Medycyna 3-4 (2014), s. 130-160.

KorYTKOwsKa Anna: Problem zgodności Kodeksu etyki lekarskiej z Konstytucją RP, Ruch Prawniczy, Ekonomiczny i Socjologiczny 1 (2009), s. 53-69.

KozIK Michał: Odpowiedzialność zawodowa lekarzy, [w:] Agnieszka FiUtak [i IN.]: Odpowiedzialność prawna pracowników medycznych. Przepisy - przykłady - orzecznictwo, Warszawa: C.H. Beck 2013, s. 3-92.

Kubiak Rafał: Prawo medyczne, Warszawa: C.H. Beck 2010.

KuBiaK Rafał: Tajemnica medyczna, Warszawa: C.H. Beck 2015.

Kuczma Paweł: Adwokat jako zawód zaufania publicznego w orzecznictwie Trybunału Konstytucyjnego, Palestra 3-4 (2012), s. 146-157.

Kulesza Michał: Zawód zaufania publicznego, [w:] Zawody zaufania publicznego a interes publiczny - korporacyjna reglamentacja versus wolność wykonywania zawodu. Materiały z konferencji zorganizowanej przez Komisję Polityki Społecznej i Zdrowia Senatu RP przy współudziale Ministerstwa Pracy i Polityki Społecznej pod patronatem Marszałka Senatu RP Longina Pastusiaka, 8 kwietnia 2002 r., Warszawa: Dział Wydawniczy Kancelarii Senatu 2002, s. 149-152.

Ł̨̨TowsKa Ewa: Kara za zabójstwo kwalifikowane - problematyka konstytucyjna, Państwo i Prawo 10 (2006), s. 5-24.

Maksymowicz Krzysztof, SzewioŁa Tadeusz: Okoliczności obciążające w ujęciu teorii i orzecznictwa Sądu Najwyższego, Nowe Prawo 3-4 (1982), s. 52-66.

MareK Andrzej: Kodeks karny. Komentarz, Warszawa: Wolters Kluwer 2007.

MoRAwski Lech: Wykładnia w orzecznictwie sądów. Komentarz, Toruń: TNOiK Dom Organizatora 2002.

NojszewsKa Ewa: System ochrony zdrowia w Polsce, Warszawa: Wolters Kluwer 2011.

NowACKi Józef: Studia z teorii prawa, Kraków: Kantor Wydawniczy Zakamycze 2003.

ODROWĄŻ-SYPNIEWSKI Wojciech: W sprawie wykładni art. 17 Konstytucji Rzeczypospolitej Polskiej, Przeglad Sejmowy 2 (2001), s. 71-73.

OpAlEk Kazimierz, WróblewsKi Jerzy: Zagadnienia teorii prawa, Warszawa: Państwowe Wydawnictwo Naukowe 1969.

PATRYN Rafał: Lekarski egzamin państwowy. Prawo medycznie orzecznictwo lekarskie. Kompendium wiedzy dla absolwentów wydziałów lekarskich i lekarsko-dentystycznych, Warszawa: Medyk 2014.

PITERA Jakub: Charakterystyka instytucji zaufania publicznego w orzecznictwie Trybunału Konstytucyjnego, Sądu Najwyższego oraz sądów powszechnych, Kwartalnik Prawa Publicznego 4 (2007), s. 145-162.

Pollak Kurt: Uczniowie Hipokratesa, tłum. T. Dobrzański Warszawa: Wiedza Powszechna 1970.

SAKowicz Andrzej: Sankcja bezwzględnie oznaczona (uwagi krytyczne na tle art. 148 § 2 k.k.), Państwo i Prawo 5 (2006), s. 18-31.

SARNECKI Paweł: Glosa do wyroku Sądu Najwyższego z dnia 29 maja 2001 r., sygn. I CKN 1217/98, Palestra 5-6 (2002), s. 185-188.

SARNeCKI Paweł: Pojęcie zawodu zaufania publicznego (art. 17 ust. 1 Konstytucji) na przykładzie adwokatury, [w:] Konstytucja - Wybory - Parlament. Studia ofiarowane Zdzisławowi Jaroszowi, red. L. Garlicki, Warszawa: Liber 2000, s. 164-163.

STYChleRz Anna: Lekarz przed sądem lekarskim, Forum Medycyny Rodzinnej 4 (2009), s. 340-342.

TABernacka Magdalena: Pojęcie zawodu zaufania publicznego, Przegląd Prawa i Administracji t. LXII (2004), s. 287-302.

TaCzKowska Joanna: Zawód dziennikarza w Polsce. Między misją a posłannictwem, Bydgoszcz: Wydawnictwo UKW 2012. 
TADAJCZYK Konrad: Status społeczno-prawny i odpowiedzialność lekarza w prawie rzymskim, Łódź: Drukarnia Cyfrowa 2014.

TRUBALSKI Artur: Samorządy zawodów zaufania publicznego na przykładzie samorządu radców prawnych. Analiza konstytucyjnoprawna, Studia Iuridica Lublinensia t. XXI (2014), s. 223-238.

WanATOwsKa Wiesława, Kulesza Witold: Odpowiedzialność prawna lekarza, Warszawa: Wydawnictwo Prawnicze 1988.

WIERCZYŃSKi Grzegorz: Redagowanie i ogłaszanie aktów normatywnych. Komentarz, Warszawa: Wolters Kluwer 2016.

WiLCZEK-RuŻYCZKa Ewa: Wypalenie zawodowe pracowników medycznych, Warszawa: Wolters Kluwer 2014.

WoJTCZAK Krystyna: Reglamentacja form wykonywania zawodów zaufania publicznego w rozwiązaniach prawa polskiego i państw Unii Europejskiej, [w:] Zawody zaufania publicznego a interes publiczny - korporacyjna reglamentacja versus wolność wykonywania zawodu. Materiały z konferencji zorganizowanej przez Komisję Polityki Społecznej i Zdrowia Senatu RP przy współudziale Ministerstwa Pracy i Polityki Społecznej pod patronatem Marszałka Senatu RP Longina Pastusiaka, 8 kwietnia 2002 r., Warszawa: Dział Wydawniczy Kancelarii Senatu 2002, s. 39-47.

WoŁPIUK Waldemar: Zawód zaufania publicznego z perspektywy prawa konstytucyjnego, [w:] Zawody zaufania publicznego a interes publiczny - korporacyjna reglamentacja versus wolność wykonywania zawodu. Materiały z konferencji zorganizowanej przez Komisję Polityki Społecznej pod patronatem Marszałka Senatu RP Longina Pastusiaka 8 kwietnia 2002 r., Warszawa: Dział Wydawniczy Kancelarii Senatu 2002, s. 19-24.

WYREMBAK Jarosław: Naruszenie zasad etyki lub deontologii jako podstawa odpowiedzialności zawodowej lekarza, Studia Iuridica t. XLIII (2004), s. 245-248.

Wyrembak Jarosław: Kodeks etyki lekarskiej a system prawa, Państwo i Prawo 10 (2003), s. 30-44.

ZIELIŃsKa Eleonora: Odpowiedzialność zawodowa i karna lekarza w Polsce (Perspektywa prawnoporównawcza), Państwo i Prawo 3 (1991), s. 26-40.

ZIELIŃSKA Eleonora: Odpowiedzialność zawodowa lekarza i jej stosunek do odpowiedzialności karnej, Warszawa: Liber 2001.

ZoLl Andrzej: Założenia polityki karnej w projekcie kodeksu karnego, Państwo i Prawo 5 (1994), s. 3-11.

ŻEBROwSKI Jan: Socjologiczne aspekty zawodu i pozycji społecznej - droga do tożsamości wychowawców profesjonalnych, Studia Gdańskie. Wizje i Rzeczywistość t. V (2008), s. 24-43.

\section{INNE OPRACOWANIA I DOKUMENTY}

Komunikat z badań. CBOS. Opinie o funkcjonowaniu opieki zdrowotnej. BS/113/2016, Warszawa: CBOS 2016.

Komunikat z badań. CBOS. Prestiż zawodów. BS/164/2013, Warszawa: CBOS 2013.

Komunikat z badań. CBOS. Prestiż zawodów. BS/8/2009, Warszawa: CBOS 2009.

Komunikat z badań. CBOS. Opinia społeczna na temat zawodów zaufania publicznego. BS 73/2004, Warszawa: CBOS 2004.

Komunikat z badań. CBOS. Prestiż zawodów. BS/32/1999, Warszawa: CBOS 1999.

Nowe kodeksy karne z uzasadnieniem, Warszawa: Wydawnictwo Prawnicze 1997.

Obwieszczenie nr 1/04/IV Prezesa Naczelnej Rady Lekarskiej z dnia 2 stycznia 2004 r. w sprawie ogłoszenia jednolitego tekstu uchwały w sprawie Kodeksu Etyki Lekarskiej, Biuletyn NRL z 2003 r. Nr 6/80. 


\section{Netografia}

Projekt ustawy o zmianie ustawy - Kodeks karny oraz niektórych innych ustaw [w:] https://legislacja.rcl.gov.pl/docs//2/12320403/12565603/12565604/dokument378684.pdf [dostęp: 2.02.2019].

Lekarze w badaniach opinii społecznej 2017, [w:] https://www.nil.org.pl/_data/assets/pdf file/0007/125566/Raport-Lekarze-w-badaniach-opinii-spolecznej-w-2017-roku.pdf [dostęp: 2.12.2018].

Kodeks Etyki Lekarskiej, [w:], http://www.nil.org.pl/_data/assets/pdf_file/0003/4764/Kodeks-Etyki-Lekarskiej.pdf [dostęp: 4.12.2018].

\section{PRZESŁANKI I KONSEKWENCJE ODPOWIEDZIALNOŚCI ZAWODOWEJ LEKARZY - WYBRANE PROBLEMY W ŚWIETLE PRZEPISÓW USTAWY O IZBACH LEKARSKICH}

\section{Streszczenie}

Niniejszy artykuł poświęcono wybranym problemom, dotyczącym reżimu odpowiedzialności zawodowej lekarzy. Mając na uwadze specyfikę zawodu lekarza oraz kierowane nierzadko pod jego adresem wyobrażenia społeczne (co de facto nie pozostaje obojętne z punktu widzenia samej istoty wspomnianego reżimu odpowiedzialności), podjęte rozważania rozpoczęto od analizy empirycznej, prezentującej społeczne oceny wobec osób wykonujących wspomniany zawód. W dalszej kolejności odwołano się do regulacji ustawy o izbach lekarskich. Przedmiotem szczegółowych rozważań uczyniono przesłanki odpowiedzialności zawodowej członków izb lekarskich, jak również normatywne wskazania rządzące wymiarem kary, orzekanej w przypadku popełnienia przewinienia zawodowego.

Słowa kluczowe: zasady etyki zawodowej; zawód lekarza; odpowiedzialność w służbie zdrowia

\section{PREMISES AND CONSEQUENCES OF THE PROFESSIONAL LIABILITY OF DOCTORS - SELECTED ISSUES IN THE LIGHT OF THE ACT ON MEDICAL CHAMBERS}

\section{Sum mary}

This article is devoted to selected problems concerning the regime of professional liability of doctors. Bearing in mind the specific nature of a doctor's profession and often social ideas directed at it (which de facto does not remain indifferent from the point of view of the very essence of the aforementioned regime of liability), the considerations started with an empirical analysis, presenting social assessments towards people performing the said profession. Subsequently, reference was made to the regulations of the Act on Medical Chambers. The premises for professional liability of members of medical chambers, as well as normative indications governing the level of punishment imposed in the case of professional misconduct have been the subject of detailed consideration.

Key words: principles of professional ethics; doctor's profession; liability in the health service 